ходящих от сифплитических родителей, особенно от матерей-сифилитичек, тав гак даже при довольно строгом ограничении круга бессимптомных детей, оставленных без лечения, наблюдаются все же случаи появления положительной $\mathrm{RW}$. 4) Наиболее желательным при врожденном сифилисе в раннем детстве, особенно для проведения первого гурса лечения, является стационарное лечение в венотделениях больниц или в специальных детских учреждениях, куда грудные дети принимаются вместе с матерями. 5) Смепанное ртутно-сальварсанное лечение дает .учшие результаты в сравнении с чисто-ртутным в отношении частоты рецидивов, влияния на $\mathrm{RW}$ и на общее развитие ребенка. 6) Дети сравнительно хоропо переносят сравнительно больпие дозы неосальварсана-до 0,02 накило веса. $P$.

43. Сифилис жслудка-весьма редкое явление. Диагностика его трудна. С некоторой уверенностью можно говорить о сифилисе желудка при лоложительном результате антисифилитической терапии; с больпей уверенностью это можно утверждать при обнаружении спирохэт в иссеченном участке желудюа; иногда, однако, и рентгеновское исследование дает характерную картину. Herrmann (British journal of radiology, XXXII, p. 325) описывает картину приподнятого, меньпенных размеров желудка, который очень быстро наполнялся и опорожнялся. у pyłorus'a определялся дефект наполнения, перистальтика была неравномерная. Картина в общем напоминала рак. Исследование крови и желудочного сока дало по.лжительную RW. Проведенная антилюетическая терапия дала блестящий әффектисчезновение дефекта и др. симптомов, на основании чего автор считает свой случай доказанным случаем сифиллиса желудка.

44. Сияилис почевого пузыря, по R i е s'y (Mon. f. Harnkr., 1928, H. 12), представляет собою относительно-редкое явление. В больпинстве случаев здесь имеют место проявления третичного lues'a, в форме похожих на папилломы гумм, переходящих потом в язвы. Цистоскопически гуммы эти зачастую бывает нельзя отличить от папиллом, и тольго анамнез больных и основательное исследование других органов дают точки опоры для правильного диагноза. Гораздо реже наблюдаются в пузыре вторичные сифилитические проявления в виде острого или хронического цистита с пиурией и поллаклурией. Во всех этих случаях лучпим средством для борьбы с болезнью является әнергичное общее антилюетическое лечение, но не какие-либо местные процедуры.

$P$.

\title{
м) Гонороея.
}

45. Лечение хронической гонорреи матки и маточных придатков вакииной из жсивых гонококков. L o e s e r (Med. Kl., 1928, № 25) получил очень хоропие результаты при хронической гоноррее матки и ее придатков от подкожного введения живых гонококков. Напротив, в острых и подострых случаях,-за: исключением липь случаев острого гонорройного артрита,-это лечение оказывается недействительным. Технически метод проводится след. образом: гной соверпенно свежей гонорреи засевается на K о с h'овский гровяной агар.; после 1-го, maximum 2-х пассажей гонококки культивируются в пробирках с асцит-агаром, на. косых поверхностях которого делается змееобразный штрих; выроспие здесь гонококки смываются 3-мя куб. с. стерильного физиологического раствора, и $1-2$ куб́. с. этой взвеси при помощи обычного пприца впрыскиваются бо.льной под кожу левого плеча. Обычно при этом вводится под кожу 2-4 миллиарда зародышей. После впрыскивания наблюдается чрезвытайно резкая местная реакция,-получается нечто вроде ограниченной флегмоны; $t^{0}$, однако, лишь редко поднимается выше 38; боли, неособенно сильные, проходят через 24-48 ч. Если первая инъекция не дает эффекта, что бывает в весьма редких случаях, то через 14 дней впрыскивание можно повторить. $P$.

46. Локализаиия гонорройного артрита. М а у r и B r e m e r (Münch. $\mathrm{m}$. VV., 1928, № 24) напел, что обцепринятое мнение, будто при гоноррее поражается только один сустав, неправильно. Из 5778 гонорройных больных $2,2^{\circ} \%$ дали заболевание суставов, причем у $45 \%$ оно было в форме чистого моноартрита, у $28 \%$-полиартрита и у $27 \%$-полиартрита, перешедшего в моноартрит. Переход моноартрита в полиартрит не встречался. Чаще всего поражался коленный сустав, затем в убывающем порядке пли ручные и кожные суставы, плечевой, локтевой и остальные мелкие. В молодом возрасте чаще наблюдался моноартрит, в пожилом-полиартрит. Из других инфетций сифилис на 4800 случаев дал поражение суставов в 1,1\%, в том числе в $20 \%$ в виде чистого моноартрита и в $80 \%$-полиартрита; в сред- 